\title{
Argentine and Egyptian History Entangled: From Perón to Nasser
}

\author{
LILY PEARL BALLOFFET*
}

Abstract. This article presents an entangled history of Argentina and Egypt in the years surrounding the 1952 Egyptian Revolution. It combines diplomatic, migration and anti-imperial activism histories to delineate the intellectual and institutional links between these nations from the late I940s to the I950s - from the rise of Peronism through to Nasser's management of the Suez Canal crisis of 1956. Diverse Argentine social and political sectors saw parallels between the anti-imperial struggles in the Arab world and in Latin America. Though with differing and sometimes competing agendas, these groups learned and deployed the language of nonalignment and South-South solidarity in the escalating Cold War.

Keywords: Argentina, Egypt, Global South, Arab Diaspora, Cold War, Non-Aligned Movement

\section{Introduction}

This article analyses the developing relationship between Argentina and Egypt in the years surrounding the I952 Egyptian Revolution. Interweaving diplomatic, Arab Diaspora and anti-imperial activism histories, this study provides evidence of the intellectual links and institutional networks that join Egyptian history to Argentina. During this time, the spheres of Arab and Latin American state actors, Middle Eastern diaspora communities in Latin America and broader anti-imperialist activisms of the early Cold War era overlapped and were mutually influential. Furthermore, the set of relationships, mirrored rhetoric and organisational exchanges highlighted here represent an early moment of Global South exchange in the lead-up to the NonAligned Movement's galvanisation by the early i960s. This approach differs from previous treatments of Argentine-Middle Eastern international relations in its chronological scope, geographic focus, range of archival material and attention to the central role of diaspora communities in mediating the 'South-South' dialogues between Argentines and Egyptians. By reference to

Lily Pearl Balloffet is assistant professor in the Department of History at Western Carolina University. Email: lgballoffet@wcu.edu.

* Special thanks to Christine Mathias for her input on an early draft of this article. 


\section{Lily Pearl Balloffet}

diplomatic archives, the diasporic press and personal correspondence, I argue that Argentina provided a linguistic register, intellectual base and source of material aid for the Egyptian revolutionary project.

In July 1952, the international media rushed to record the revolutionary and tragic events that unfolded in Egypt and Argentina over the course of a few days. On 23 July, young Egyptian army officers ousted King Farouk and set Egypt on the path to revolution. Three days later, and across the Atlantic, populist leader Juan Domingo Perón lost his wife and main political ally, Eva, to cancer. He was at that point approaching the end of his first six-year presidential term (his second term, which lasted only three years, ran on from the first, and his third term, a year in length, followed his return from exile in 1973). By the end of July 1952, both Argentines and Egyptians found themselves in the midst of national transition - a new phase of the Peronist national project, and a new revolutionary state. For Argentine citizens who could trace their roots back to Arabic-speaking immigrants from the Eastern Mediterranean, or who had themselves emigrated from that region, the events of 1952 led to opportunities for advocating a closer relationship between Argentina and the Arab world. For non-Arab Argentines (government officials and private citizens alike), this early Cold War moment held the possibility of building new Global South political and economic relationships.

The 1952 Egyptian Revolution, followed by the rise of President Gamal Abdel Nasser, inspired many Argentines to articulate a connected history between Egypt and Argentina. Many also envisioned a connected future between these nations and peoples. This article situates these unfolding events within the broader context of the early Cold War era and nascent Non-Aligned Movement (NAM) to bring new perspective to this global moment. The fact that many important Latin American leaders hoped fervently for South-South solidarities at this moment has never been in question. One need look no further than Cuba's post-1959 attempts to export its revolutionary model, and Che Guevara's optimistic courtship of Afro-Asian leaders such as Nasser and Ghana's Kwame Nkrumah. Solidarities of the Global Left - both hoped-for and real - proliferated in the 'Third World', especially surrounding landmark moments of transregional anti-colonial movements. These included the 1955 Bandung Conference (from which Latin America was conspicuously absent). While a rundown of Latin America's formal diplomatic history leaves the impression that, on balance, the region arrived rather late to the rising NAM, this overlooks the profusion of smaller-scale South-South exchanges.

It is true that Latin America did not begin to send delegations to the formal reunions of the central Afro-Asian international committee that arose from Bandung - the Organization of Solidarity of the Peoples of Africa and Asia 
(OSPAA) - until OSPAA's I 966 Havana meeting. ${ }^{1}$ In the Argentine delegation to the meeting, the presence of the Left was prominent. ${ }^{2}$ This was undoubtedly a key moment in the mobilisation of a Global Left within international organisational engines such as $\operatorname{OSPAA}(\mathrm{L})$. However, this article reveals another set of complex tricontinental solidarities that predated this mobilisation. In Argentina, these came in the form of cultural exchanges, activisms and overlapping developmentalist ideologies. Diaspora communities, anti-imperialists, state actors and Perón himself (both during his presidential terms of $1946-52$ and his subsequent exile) sought to mediate and foster these tricontinental solidarities. In return, Egyptians (both politicians and non-state actors) recognised Argentina and Argentines as connected to the longer Egyptian struggle for sovereignty against imperial forces that began with the 1952 Revolution, and intensified with the 1956 Suez Canal Crisis. Methodologically, this study provides a model for tying diasporic histories into Latin American diplomatic and cultural narratives.

The burgeoning relationship between Argentines and Egyptians from the early I950s onward is part of a much longer historical relationship between Latin America and the Middle East. Countries like Brazil, Mexico and Argentina experienced migration 'booms' during the lead-up to World War I that brought more than a quarter of a million Syrian Ottomans to the Americas. ${ }^{3}$ During this period, the Ottoman Empire saw 20 per cent of Greater Syria's population emigrate to begin new lives abroad. Scholars of Middle East migration studies have revealed the transnational flows of people, goods and ideologies that circulated amongst this diaspora's public sphere. ${ }^{4}$ With this field's historiographical emphasis on the pre-World War II era, however, there exists a chronological gap in the literature on the

I At that 1966 meeting, OSPAA became 'OSPAAL' (to incorporate 'Latin America').

${ }^{2}$ Delegates included Peronist radical John William Cooke, representatives of the Argentine Communist Party and Marxist-Leninist vanguards. Donald C. Hodges, Argentina's 'Dirty War': An Intellectual Biography (Austin, TX: University of Texas Press, I991), p. 95.

${ }^{3}$ Immigrants hailed from present-day Syria, Lebanon and Palestine.

${ }^{4}$ Arab Diaspora scholarship attests to robust migratory links between Latin America and the Arabic-speaking Eastern Mediterranean starting in the late nineteenth century. For example: Steven Hyland, "'Arisen from Deep Slumber": Transnational Politics and Competing Nationalisms among Syrian Immigrants in Argentina, 1900-1922', Journal of Latin American Studies, 43: I (201 I), pp. 547-74; Andrew Arsan, John Karam and Akram Khater, 'On Forgotten Shores: Migration in Middle East Studies and the Middle East in Migration Studies', Mashriq \& Mahjar: Journal of Middle East and North African Migration Studies, I: I (2013), pp. I-7. In the broader field of global migration studies, frameworks such as Nina Glick Schiller and Georges Fouron's 'long-distance nationalisms' have theorised diaspora communities' modes of relating to homelands and patterns of diasporic individuals acting as mediators or interlocutors between the nations of their residence vs. those of birth/heritage. Nina Glick Schiller and Georges Fouron, Georges Woke Up Laughing: Long-Distance Nationalism and the Search for Home (Durham, NC: Duke University Press, 200 I). 
global Arab Diaspora ('Mahjar' in Arabic) when it comes to post-war dynamics between diaspora communities, host countries and homelands. This article addresses said paucity, while building on this constellation of migration and diaspora scholarship.

Piecing together a history of Argentine-Egyptian relations also builds on studies that examine the political and diplomatic ties between these world regions. This task contributes to a larger historical field of 'South-South' cooperations and connections that unfolded against African, Asian and Latin American backdrops during the Cold War. 5 Analysing the role of diasporic Arabs in the connected history of Argentina and Egypt bridges migration and diplomacy literature, bringing the diaspora into our understanding of the state and civil society post-World War II.

By bridging these fields, we see how the tides of public opinion and political posturing appeared amongst Latin Americans of all stripes who saw an Arab reflection of their own situation. Formal diplomatic correspondence between Argentine, Syrian, Lebanese and Egyptian bureaucrats during World War II and Perón's first term in office reveals a rich story when read in tandem with the Arab-Argentine press, academic treatises and international non-governmental organisation reports from the I 940 and I950s. This was an era in which both Arab and Latin American nations experienced the rise of mass politics, populist leadership figures and a keen awareness of the emerging postwar global order. During this time, the Argentine state made clear efforts to cultivate strong diplomatic relationships with many Middle Eastern nations beginning in 1945 - with Egypt in particular. ${ }^{6}$

To delineate Argentine-Egyptian relations during this period, I integrate analyses of the actions of politicians, intellectuals and local Argentine agitators of Arab descent. Three dimensions of Argentine-Egyptian relationships will

S See: Jessica Stites Mor, 'The Question of Palestine in the Argentine Political Imaginary: Anti-Imperialist Thought from Cold War to Neoliberal Order', Journal of Iberian and Latin American Research, 20: 2 (2014), pp. 183-97; Ignacio Klich, 'Toward an ArabLatin American Bloc? The Genesis of Argentine-Middle East Relations: Jordan, 1945-54', Middle Eastern Studies, 3 1: 3 (1995), pp. 550-72. For scholarship with a transnational political focus on Middle East-Latin American relations, see: Hishaam Aidi, Redeploying the State: Corporatism, Neoliberalism, and Coalition Politics (New York: Palgrave Macmillan, 2009); Federico Vélez, Latin American Revolutionaries and the Arab World: From the Suez Canal to the Arab Spring (Aldershot: Ashgate, 2016); Luis Mesa Delmonte (ed.), Las relaciones exteriores de Siria (Mexico City: El Colegio de México, Centro de Estudios de Asia y África, 2013).

6 In 'Toward an Arab-Latin American Bloc?' Klich utilised diplomatic cables to demonstrate the mutual desire of Argentina and Jordan to gain international respect after World War II. Correspondence from the Argentine Ministry of Foreign Relations (AMREC) from 1939 to I 950 also documents a steady increase in secret cables, official reports, press clippings and petitions between Argentina and Syria, Lebanon, Iraq, Saudi Arabia and Jordan. The archived documentation on Egypt far exceeds that on any other nation. AMREC, Buenos Aires, División Política (DP), Arab States, Syria/Lebanon/Egypt, 1939-50. 
be explored: I) Arab-Argentine journalistic and translation projects that offered a rhetorical register to Egyptian revolutionaries; 2) diplomacy - by state officials and self-appointed citizen-diplomats; and 3 ) anti-imperial solidarities. The sections that follow posit the connected history of Argentina and Egypt as a starting point for reconstructing Latin American-Middle East relations at the dawn of the Cold War.

\section{Egypt Igs2 in the Diaspora}

Diasporic institutions and press organs from the Arab-Argentine community responded to the 1952 Egyptian Revolution with extensive press coverage. The response of Mahjar journalists to events in I 950 Egypt reveals diasporic viewpoints on the relationship between Argentina and Egypt. It also exposes statelevel exchanges and transnational information networks that otherwise remain hidden. From the nineteenth-century immigration boom onwards, Argentina boasted a vibrant array of diasporic press organs run by Italians, Spaniards, Germans and Middle Eastern collectivities, among others. Newspapers and magazines routinely intermingled news stories on Argentine politics and current events with news from the 'homeland' - in the case of the Middle Eastern newspapers, Syria and/or Lebanon. This Levantine focus mirrored the demographic composition of Middle Eastern diaspora communities in the Southern Cone. In terms of Egyptians living in Argentina, there were almost none to speak of, save the few individuals occupying diplomatic posts at the Egyptian Legation in Buenos Aires (established in 1947). Despite the lack of a direct heritage tie, however, events in 1952 pushed Egypt into the spotlight of Argentina's diaspora press.

The Arab-Argentine community's outpouring of attention to the 1952 Revolution and its aftermath did not stem from a strictly national heritagebased empathy. Rather, the shower of commendations that the young Egyptian men of the Free Officers' Movement received from this community's press was the result of a twofold affinity that many individuals felt. ArabArgentines identified as both Argentines and Arabs as they extolled those who dismantled the monarchy, ushering Egypt into a new era. They were part of a broader movement amongst Argentine citizens and statesmen to recognise Latin America and Afro-Asia as world regions with a common history and destiny. Simultaneously, they represented a diasporic limb of the largescale mobilisations in support of the Egyptian project that occurred across the Afro-Asian world.

Expressions of this deep identification with the Egyptian cause took numerous forms in the diasporic press. These included emphatic comparisons between Argentine and Egyptian leaderships, the juxtaposition of Egyptian and Argentine current events, and instances of symbolic adoption of 


\section{Lily Pearl Balloffet}

Egyptian identity. This identification with events and people in Egypt spurred diasporic Arabs in Argentina to cultivate networks of communication between Argentina and Egypt. They engaged in translation projects and press campaigns that ultimately resulted in rendering Peronist doctrine accessible to an Arabic-speaking audience.

The few academic works that look comparatively at Argentine and Egyptian history in the mid-twentieth century focus on similarities or links between Presidents Perón and Nasser. Diasporic press coverage of the 1952 Revolution reveals that Arab-Argentines eagerly drew comparisons between Argentine and Egyptian leaders even before Nasser came to power. When news reached Argentina that Farouk had fallen, and that a SudaneseEgyptian army general by the name of Mohammad Naguib was the front man for a series of sweeping reforms to be carried out in Egyptian society, Arab-Argentine writers immediately drew connections. In Buenos Aires and in the provinces, journalists in the Arab-Argentine press jubilantly compared Generals Naguib and Perón. They also drew parallels between the political trajectories that they predicted for Argentina and Egypt.

One of the most enthusiastic tracts on the similarities between Perón and Naguib appeared in the northwestern city of San Miguel de Tucumán's newspaper El Eco de Oriente, owned and edited by Lebanese-Argentine Najib Baaclini. 'Egypt Has Her Own Perón Now', proclaimed the 1953 article.7 The piece included an interview transcript of Baaclini's conversation with Egyptian journalist Ahmed Mattar, who was residing in Argentina and serving as a functionary of the Egyptian Legation. Not only does this example demonstrate the perceived similarities in leadership between Naguib and Perón, it furthermore provides evidence of documentation and communication circulating between Argentine and Egyptian political actors and diasporic mediators.

The constant theme in Baaclini's interview with Mattar was the resemblance between Naguib and Perón - in their action, philosophy, and even physical appearance. Mattar concluded with: 'Naguib? ... He is the Perón of Egypt! You Argentines can understand Naguib perfectly, because you have had to fight doggedly, as we have, for your liberty, and you have achieved [this] thanks to your magnificent leader, who is similar to Naguib.' Repeatedly, Mattar insisted upon the reciprocal nature of the affinity that he sensed between the two men. Both he and Baaclini carefully noted that it was not merely the case that Naguib resembled Perón. In equal measure, Perón was like Naguib - thus placing the two men on equal footing as

7 Najib Baaclini, 'Naguib, visto por un viejo amigo: "Egipto tiene ya su Perón"', El Eco de Oriente (Tucumán), 24 Feb. 1953, p. 2. Translations from original sources are by the author, unless otherwise noted.

${ }^{8}$ Ibid. 
world leaders connected in the struggle for sovereignty, patria, and pueblo. When asked what Naguib was doing for his patria, Mattar pointed to the parallel rhetoric of social justice that he observed in both leaders: 'In his discourses, he has employed words and concepts that remind us of the great Argentine president.' I In addition to highlighting parallel aspects of Naguib and Perón's bearing and rhetoric, the article also made clear that there were concrete exchanges of information and strategy taking place between the Egyptian and Argentine leaders.

Mattar reported that he had spoken with Naguib at length about the Peronist project, and acted as a courier of 'abundant documentation' from Buenos Aires to Cairo. Specifically, he mentioned that on his upcoming trip to Egypt he would be 'carrying in his suitcase [Perón's] Segundo Plan Quincenal ...' 'о Perón's First and Second Five-Year Plans (1946, 1952) were landmark documents in his administration. They outlined political, economic and social goals for the nation. This provincial Arab-Argentine newspaper's interview with an Egyptian functionary is an important link in helping us to grasp the mechanics of communication and exchange between Arab and Latin American states outside of formal diplomatic realms. As Hishaam Aidi notes in his comparative study of Egyptian and Mexican corporatism, 'After the 1952 Revolution, Egyptians - leaders and laymen - had looked toward Latin America for solutions and prescriptions for economic autonomy and freedom from the neocolonial yoke.' ${ }^{1}$ Until now, however, scholarship has yet to produce a clear picture of the exact workings of these exchanges and communications networks. The diasporic press provides information about the communication and exchanges between Arab-Argentines and their Egyptian counterparts that gives concrete dimension to the more ephemeral claim that Egypt 'looked toward' Latin America during this period. It also reveals diasporic actors (like Mattar or Baaclini) who were interlocutors in important exchanges of documents and information for Egyptians (like Naguib) engaged in the revolutionary project.

A few provinces away from Tucumán, the Córdoba-based newspaper Mundo Arabe used a different method of juxtaposing Egypt and Argentina for its readers. Its focus was not on Naguib and Perón themselves, but rather on key aspects of their agrarian and economic programmes. On consecutive pages, it presented lengthy articles about agrarian reform in the two nations - one penned by an Argentine journalist, and one by then-Officer Gamal Abdel Nasser. Thus, readers could inform themselves about the Argentine Institute for the Promotion of Trade and the Plan Quincenal in counterpoint with Naguib's agrarian reform and the Egyptian fellah

9 Ibid.

${ }^{10}$ Ibid. (ellipsis original).

${ }^{11}$ Aidi, Redeploying the State, p. I. 
(agricultural labourer). ${ }^{12}$ The gains for Argentina's agrarian sector under Perón were 'similar to [those for] Arab nations currently living in a fecund time of popular progress, redemptive revolution', concluded the editor of Mundo Arabe. With this, editors deftly converted a discussion of Argentine agrarian reform into evidence of significant similarities between Argentina and 'Arab nations living in a time of revolution' - obviously, a reference to Egypt. This conspicuous coincidence of subject matter in consecutive articles on Egypt vs. Argentina was not unique to Mundo Arabe - other examples include a pair of articles on paper factories and their labour unions in the two nations which appeared in Tucumán's El Eco de Oriente. ${ }^{13}$

In some newspapers, eager to show the Arab-Argentine collectivity's closeness to the Egyptian cause, journalists adopted the symbolic label of 'la colectividad siriolibanesa y egipcia' ('Syrian-Lebanese and Egyptian collectivity') when speaking of their heritage community. The number of Egyptian civilians living in Argentina was not actually significant, yet beginning in 1952 ArabArgentine press organs such as the Diario Sirio Libanés and Assalam often made equal mention of the Syrian, Lebanese and Egyptian heritages of their community. Taken together with examples of diasporic voices who articulated similarities and connections between Argentina and Egypt, the adoption of a symbolic Syrian-Lebanese-Egyptian identity suggests the desire to position diasporic Arabs as specially qualified interlocutors between Argentina and Egypt. This was an exciting moment for a heritage community attuned to opportunities to draw Argentine attention to the Arabic-speaking Eastern Mediterranean. From the outset of the 1952 Revolution Arab-Argentines strategically positioned themselves as mediators and facilitators of the SouthSouth dialogues that they hoped would follow.

As Raanan Rein and Ariel Noyjovich demonstrate in their work on ethnicity and citizenship discourse under Perón, this position as interlocutors between Argentina and the 'homeland' was one that Perón actively encouraged in diaspora communities such as the Jewish, Japanese and Arab collectivities. ${ }^{14}$ Thus, in part we can see Arab-Argentine desire to act as intermediaries between Argentina and a revolutionary Egypt as a response to a newly opened political space in Argentina, in which the national leadership actively courted the support of immigrant groups formerly excluded from national imaginaries of citizenship. Beyond this factor, to further understand why many Arab-

${ }^{2}$ Enio Atilio Mastrogiovanni, 'La gran obra argentina de afirmación de los derechos de los trabajadores del campo', Mundo Árabe (Córdoba), i 9 Dec. 1953, p. 9. Gamal Abdel Nasser, 'La reforma agraria del general Naguib favorece la reivindicación del fellah', ibid., p. 10.

13 'Sobre solidaridad sindical habló el General Perón a obreros papeleros', El Eco de Oriente (Tucumán), 24 Aug. 1953, p. I; 'Instalarán una fábrica de papel en Egipto', ibid., p. 4.

${ }^{14}$ Ariel Noyjovich and Raanan Rein, 'Para un árabe de bien no puede haber nada mejor que otro árabe: Nación, etnicidad y ciudadanía en la Argentina peronista', Contra Relatos desde el Sur, 14 (2016), p. 58. 
Argentines wanted to see Argentina and Egypt as legitimately connected, and why they wished to mediate this new relationship, we must also historically contextualise the events of the I950s in the Middle East. Beyond the favourable conditions that a Peronist Argentine political landscape created for some ethnic minorities, broader processes of imperialism and decolonisation struggles impacted the Middle East and its diaspora.

\section{Argentine-Arab Relations}

The circulation of both private citizens and state-sanctioned diplomacy between Argentina and Egypt after 1952 was not a new phenomenon. It built upon, and was facilitated by, diasporic networks of Arabs in Latin America since the early twentieth century. Middle Eastern governments recognised the utility of these networks when it came to fundraising or drumming up political support in the transnational public sphere of the diaspora. As World War II ended, both Latin American and Middle Eastern nations hoped to improve their positions in the new world order by strengthening regional alliances. In the Middle East, the formation of the Arab League embodied the desires of many who wanted to usher in a new era of sovereignty and self-determination after decades of European mandates and intervention. Leaders from Syria, Lebanon and Egypt ramped up their diplomatic visits to Latin American nations, and official delegates of the Arab League as well as of the Higher National Committee (HNC) of Mandate Palestine made extensive international tours in the Americas. In 1947, newspapers across Argentina reported on the HNC's activities as its members visited the offices of provincial press organs and Arab immigrant associations. ${ }^{15}$ From 1946 onward, important HNC and Arab League delegates such as Mahmoud Fawzi (Arab League Assistant General of Military Affairs) regularly travelled across the Southern Cone with an entourage of Arab-Latin American intellectuals. ${ }^{16}$ The goal of these visits, and the subject matter of the discourses delivered by members of Arab League governments, was the marshalling of Latin American support (both moral and monetary) for causes such as the liberation of Palestine from British control, and, later, support for the Egyptian government post-1952. Thus, by the time of the Egyptian Revolution and Nasser's

is 'Difúndese el derecho árabe a Palestina', Los Andes (Mendoza), 2i Nov. 1947, p. 7.

${ }^{16}$ Records of these missions appear in the Arab-Argentine press and heritage association institutional records. However, the most detailed consolidated list appears in the records of the Delegación de Asociaciones Israelitas Argentinas (DAIA) - the Jewish community's umbrella organisation (established 1933). After 1947, the DAIA published sporadic reports on the activities of the Arab-Argentine community, cataloguing any suspicion or instance of anti-Jewish or anti-Israel activities unfolding in the Arab Diaspora. DAIA, Anti-Jewish Activities of the Arabs in Argentina (Buenos Aires: DAIA, 1958), p. Io. DAIA source materials can be consulted in the Biblioteca Nacional, Buenos Aires. 


\section{Lily Pearl Balloffet}

rise to power in the 1950s, many Arab-Argentines were already tapped in to networks of pan-Arab economic, intellectual and political solidarity. This created pathways for the facilitation of communication between important Egyptian and Argentine officials as dramatic socio-political shifts took place in Egypt.

In the I940s and 1950s, Arab-Latin Americans worked diligently to open pathways for diplomats and delegates who wished to spread their message and solicit monetary support for their projects. The organisation with the widest transnational reach was without a doubt the Permanent Committee of the First Panarabic Congress in America. One of the stated goals of this group was to promote the 'indestructible ties' that historically bound Latin Americans and Arabs, and to endeavour to 'make these links even closer'. The organisation boasted representatives in Argentina, Brazil, Uruguay, Paraguay, Bolivia, Colombia, Venezuela, Mexico and the United States. Argentine members of the Congress acted as translators and guides for Arab League envoys such as the 1947 Official Delegation of Arab States who toured Central and South America. ${ }^{17}$ From the mid-1940s, the Congress's Permanent Committee maintained a media presence in Argentine newspapers through letter campaigns surrounding important events in the Middle East and North Africa. ${ }^{18}$ The Committee also petitioned the Argentine Ministry of Foreign Relations at pivotal moments regarding decisions to open diplomatic relations with Lebanon, Syria and Saudi Arabia. ${ }^{19}$ By 1952, political actors in the Arab League already had a tradition of incorporating outreach to diaspora communities in both North and South America into their political campaign and rhetoric. After the Revolution, leaders like Naguib and Nasser followed suit.

Just prior to the Egyptian Revolution, the first years of Perón's presidency came at a time of heightened activism and organising within the Latin American Mahjar. A year after he took office, the United Nations would vote on Resolution i 8 I, the Plan for the Partition of Palestine. In the leadup to the 1947 vote, the Arab League, alongside many individual Middle Eastern states, sent official delegations and representatives to liaise with Latin American nations in hopes of swaying them toward voting against partition. On these visits, Arab-Argentines acted as tour guides and self-appointed

${ }^{17}$ Edy Kaufman, Yoram Shapira and Joel Barromi, Israel-Latin American Relations (New Brunswick, NJ: Transaction Books, i 979), p. i7.

18 'La iniciación de relaciones diplomáticas con Arabia Saudita', La Nación (Buenos Aires), i 8 Feb. 1946; AMREC, Buenos Aires, DP, Países Árabes 22/1946, 'Establecimiento de relaciones con Irak, Saudi Arabia, y Egipto'.

19 AMREC, Buenos Aires, PD, Syria/Lebanon 19/1945 and 1946, 'Establecimiento de relaciones diplomáticas con la República Argentina', 'Congreso panarábigo de América Latina'. 
retinues for visiting diplomatic missions. ${ }^{20}$ Though largely unsuccessful in swaying Latin American votes firmly against partition, it is notable that, of the ten nations that abstained from the partition vote, six were Latin American. In fact, the powerhouses of the Spanish-speaking Latin American bloc - Chile, Mexico, Argentina - all abstained. ${ }^{21}$ The Arab-Argentine press avidly followed the actions of the UN Special Committee on Palestine. Arabs in the diaspora read abstention as an indication of pro-Arab leanings, and repeatedly tied the Palestinian question to other liberation and antiimperialist struggles going on elsewhere on the globe in the I940s and i950s. In the wake of 1952, at least one Palestinian-Argentine saw the Revolution as a hopeful turning point in both the fate of Palestine and the future of Arab-Latin American solidarities. Issa Nahkleh, a Palestinian member of the Arab Higher Committee (the political organ of Arab Palestinians in the British Mandate period), immigrated to Argentina following the 1947 Palestinian Nakba. ${ }^{22}$ He founded the magazine América y Oriente with the express purpose of facilitating Arab-Latin American conversations about mutual anti-imperialist agendas post-1952. Meanwhile, at the state level, Perón's government trod a careful line on the issue. Perón and the Foreign Ministry cultivated relationships with Arab League states while alternately granting audiences to representatives from the Jewish Agency (a nonprofit organisation founded in 1929 to link Jewish communities around the world), as well as pro-Israel groups. The strategy appeared successful enough: Argentina's election to the UN Security Council only two months before the Partition vote was largely attributed to wide Arab bloc support.

The following year, the 1948 Arab-Israeli war resulted in Egyptian defeat and represented the Arab League's strategic failure. In Egypt, this served as a blow to King Farouk's legitimacy, and Palestine became a key symbol in the rhetoric of Generals Naguib and Nasser in the wake of the Revolution. ${ }^{23}$ In part, we can view enthusiasm on the part of ArabArgentines to act as interlocutors in the wake of the 1952 Revolution as a continuation of their activist tendencies since the beginning of Perón's administration. Meanwhile, ideologies of pan-Arab identity received mixed reviews

${ }^{20}$ Ignacio Klich, 'Arab-Jewish Coexistence in the First Half of I 900 A Argentina: Overcoming Self-Imposed Amnesia', in Ignacio Klich and Jeffrey Lesser (eds.), Arab and Jewish Immigrants in Latin America: Images and Realities (London: Routledge, 1998), p. 22.

${ }^{21}$ Raanan Rein, 'Political Considerations and Personal Rivalries: Peronist Argentina and the Partition of Palestine', Diplomacy \& Statecraft, 8: 2 (1997), p. I28. The other Latin American abstainers were Colombia, El Salvador and Honduras.

${ }^{22}$ Nakba refers to the mass expulsion/exodus of Palestinian Arabs from their homes after partition in 1947. This culminated in the establishment of Israel in May 1948, and the displacement of approximately 80 per cent of the Arab population of that territory.

${ }^{23}$ For additional historical context on the 1948 Arab-Israeli War and its geopolitical implications, see: James Gelvin, The Israel Palestine Conflict: One Hundred Years of War (Cambridge: Cambridge University Press, 2007), pp. 165-96. 
amongst different groups within the Argentine Mahjar, and the deployment of Arab nationalist or pan-Arab unity language varied between press organs of diverse political and geographic origins. Nevertheless, the ripples of different brands of Arab nationalism made their way throughout the diaspora's transnational public sphere, and form an important part of the historical context for Arab-Argentine interest in Egyptian affairs in the 1950s.

In the entanglement of Argentine and Egyptian history in the mid-twentieth century, key dates such as the 1948 Partition or the 1952 Revolution can serve as useful fulcrums. They allow us to construct a panorama of intersecting interests, pressures and influences that drove civilians and politicians to act in certain ways. These temporal fulcrums can ultimately be more useful than sideby-side comparisons of particular actors - for example Perón vs. Naguib or Nasser. In this case, using 1952 as a fulcrum allows us to extend our analysis of Argentine-Egyptian relations beyond the confines of Perón's presidency (1946-55), and beyond the realm of state-sanctioned diplomacy. Between Argentina and Egypt, we can see a clear network of communication and institutional exchange that arose following 1952. These bi-directional webs of exchange incorporate overlapping spheres of diplomatic, anti-imperialist and diaspora histories. We find archival evidence of their existence in the ArabArgentine press, Foreign Ministry records and intellectual publications.

\section{Egyptian-Argentine Connections: State and Civilian Communication}

Throughout the I950s the Arab-Argentine press publicised the role of their community in the translation of Peronist political writings into Arabic, and their subsequent transmission to Egypt. While translation projects for key Peronist doctrine documents were already under way in 1952, the Revolution gave these projects a sense of urgency and relevancy. The Revolution opened new paths of circulation between Argentina and Egypt for Arabic translations. In Córdoba, Professor José Guraieb undertook a translation of Perón's landmark 'Justicialist Doctrine' into Arabic after being granted official permission to do so by the Ministerio de Asuntos Técnicos de la Nación (National Ministry of Technical Affairs). Guraieb drew motivation from what he described as the 'social and cultural evolution' unfolding among the 'Arab peoples'. He felt an urgency and relevance in his work:

In the Near East, people are talking about Perón's Justicialismo. It has been the subject of conferences and official reports by Argentine ministries who have travelled to Arabic-speaking nations ... The logical next step is for us to present the entire work, organic and complete, to these friendly countries. ${ }^{24}$

24 'El Profesor Guraieb traducirá al idioma árabe "La Doctrina del Justicialismo", Assalam (Buenos Aires), 4 April 1952, p. I. 
By 1954, Guraieb had completed the translation, and the diaspora press heralded the news alongside reports of Nasser's ascension to the presidency. Nowhere in this press coverage did there appear significant acknowledgement of the rockiness that the Naguib-to-Nasser transition involved (whereby Nasser placed Naguib under house arrest and assumed executive office in June 1956); rather the focus remained on the potential role of Arab-Argentines in mediating relationships with the evolving Egyptian government. ${ }^{25}$

In Buenos Aires, Lebanese-Argentine writer Malatios Kouri produced an Arabic translation of La Razón de mi Vida - Eva Perón's autobiography. In May 1952 - though Eva was gravely ill with cancer - the Peróns hosted a reception at the Casa Rosada (the presidential palace) for numerous Arab-Argentine delegates as well as diplomatic representations from Syria, Lebanon and Egypt. Authorities from the Board of Directors of the Argentine Confederation of Lebanese Institutions presented General Perón with two copies of Kouri's translation of the autobiography. In separate, previous, ceremonies, Syrian and Egyptian diplomats had gifted him copies of the same text after Perón had received them in private audiences. ${ }^{26}$ Arab-Argentine press organs such as Assalam and El Diario Sirio Libanés reported on these events with great fanfare, dedicating front-page spreads in both Arabic and Spanish to the receptions in the Casa Rosada. The coverage revealed that members of the collectivity voluntarily financed the distribution of thousands of Arabic copies of the autobiography to co-nationals across Argentina. Diplomatic delegations from Syria and Lebanon took advantage of the translations produced in the diaspora, and carried copies of the autobiography home to distribute in the Levant.

Argentine officials also took interest in the events in Egypt leading up to, and in the aftermath of, the Free Officers' coup. Evidence of this interest ranges from military surveillance reports to Perón's personal correspondence. From Perón's first presidential term, his government expended large amounts of bureaucratic energy in its economic and diplomatic relationship with Egypt. Argentina formally opened diplomatic relations with Egypt in 1947, and a flood of correspondence between Argentine dignitaries in Buenos Aires, London and Cairo ensued. As the relationship between King Farouk, the military, Egypt's nationalist liberal Wafd party and British interlopers became increasingly strained, Argentine diplomats documented the rapidly shifting political panoramas.

25 'Traduce Doctrina Justicialista en lengua Árabe', Mundo Árabe (Córdoba), 27 Feb. 1954, p. 5 .

26 'Primeros ejemplares en Árabe de "La Razón de mi Vida"', Assalam (Buenos Aires), 23 May 1952, p. I; 'Tendrá enorme repercusión en el mundo árabe esta gran obra', El Diario Sirio Libanés (Buenos Aires), I 3 May 1952, p. I; 'La Confederación de Instituciones Libanesas, entidad que representa a la colectividad de ese país, hizo entrega ayer al Excmo Presidente de la Nación Juan D. Perón dos ejemplares del libro "La Razón de mi Vida" de la Sra Eva Perón, traducido al árabe', ibid., 2 I May 1952, p. I. 
Their reports were more extensive and detailed than those of any other Argentine diplomatic mission in an Arab country at the close of the 1940s. One 1949 report from envoy Francisco Bengolea to Minister of Foreign Relations Hipólito Jesús Paz even closed with a slew of surveillance-like photographs that Bengolea took to document a large military parade in Cairo that was presumably meant to demonstrate military might in the wake of Egypt's defeat a year earlier in the Arab-Israeli War. Bengolea went so far as to meticulously list the type and quantity of aircraft participating in the formation flying during the march: '2 - Meteor Gloster [sic] / I - Vampire / I 2 - Hurricane / io Lockheed / 6 - Commander / 6 - Dakota / i 5 - Spitfire / 3 - Stirling'. ${ }^{27}$ Regional politics in the Arabic-speaking Eastern Mediterranean felt extremely tense - but also exciting - to Argentine diplomats who arrived there as the I 940 S drew to a close. 'I had the Middle East in my hands', reflected Guillermo Aníbal Speroni, who arrived in Cairo as Argentina's newly appointed ambassador to Egypt, Saudi Arabia and Ethiopia in 1949. Speroni arrived as Israel, Egypt, Syria, Lebanon and Jordan signed armistice agreements to formally end official hostilities of the Arab-Israeli War. In the ambassador's words, it was the most exciting posting of his entire diplomatic career - the Middle East was, at that moment, 'a continent on the move'. Furthermore, Speroni clearly saw Peronist political doctrine as viable and influential in the Egyptian context in the years leading up to the formation of the NAM. In his eyes, Perón's Third Position philosophy of non-alignment in a Cold War world was 'the true precursor of the NAM ... Even if the [NAM leaders] didn't want to admit it.'28

As president, and into his exile, Perón made overtures to the Egyptian government and people, often using the diaspora community as interlocutors or couriers. He held exclusive interviews for Egyptian journalists travelling to Buenos Aires, and sent cultural ambassadors to Egypt in the years following 1952. In 1953, Egyptian journalist Farog Gobran travelled to Buenos Aires, where Perón granted him a lengthy interview. Gobran reported afterward: 'I have been received in the [Casa Rosada] by the ... most powerful man in South America. Perón has asked me to send this message of good will to the Egyptian people [and] spoke to me about the surprising similarity between the Argentine and Egyptian peoples.' The diaspora press eagerly picked up the news story of Perón's audience with Gobran, and obtained transcripts of their meeting. At the end of the interview, Perón referred to Argentina and Egypt as 'sister nations'. ${ }^{29}$ Between his reception of both Arab-

27 AMREC, Buenos Aires, DP, Egypt 1949, Francisco Bengolea to Hipólito Jesús Paz, 25 Nov. 1949.

${ }_{28}$ Mario Rapoport, Historia oral de la politica exterior argentina (Buenos Aires: Editorial Octubre, 2015), pp. 287-90.

29 'Declaraciones del General Perón a un periodista Egipcio: Los casos de Suez y de las Malvinas', América y Oriente (Buenos Aires), 30 Aug. 1953, p. 10. 
Argentine and Egyptian representatives (civilian and state-sponsored), Perón sent the message that he stood in solidarity with Arab and Egyptian causes, even if his foreign policy tended toward a more neutral official stance.

In addition, Perón sent cultural ambassadors to Egypt, including the prominent journalist Luis María Albamonte. In 1953 Albamonte travelled throughout the Middle East and North Africa at Perón's behest, arriving in Cairo in time to celebrate the first anniversary of the Revolution. He was received by Egyptian officials, including General Naguib and his wife. Naguib spoke of his admiration for Perón's patriotism, and requested a copy of the Segundo Plan Quincenal as well as of various other documents articulating Peronist doctrine. In response, the Egyptian Legation in Buenos Aires promptly organised the acquisition of this documentation, and forwarded it to Cairo. ${ }^{\circ}$ By tracing the paths of non-state actors like Gobran and Albamonte who formally or informally played the role of citizen-diplomat between these two nations in the 1950s, we can more clearly perceive the origins of official diplomatic exchanges that took place during this period. These journalists had the ability to act as cultural ambassadors between foreign governments and everyday Argentine or Egyptian citizens when they returned from their travels, and relayed their experiences on foreign soil.

Albamonte, for example, undertook a speaking tour of Argentina following his 1953 journey to the East. In December of that year, in Santiago del Estero, he gave a presentation about his recent travels, and spoke at length about his time in Egypt. The provincial government sponsored the event, which packed a large theatre. ${ }^{31}$ Aside from serving as a civilian envoy to Cairo in 1953 , Albamonte was the Rector of the Buenos Aires School of Journalism, and director of the newspaper El Laborista, which served as the mouthpiece for the working-class, union-based Labour Party. In 1955 Albamonte would accompany Perón during his exile from Argentina. Suffice to say, his voice carried the weight of a prominent intellectual, and his favourable review of his experiences in Egypt had the ability to reach a wide audience.

Attuned to the prospect of stronger Arab-Latin American ties, diaspora communities were often the first to report on political overtures by citizendiplomats. Only a few weeks after the Egyptian Free Officers ousted Farouk, a message from Egyptian diplomat and Secretary-General of the Arab League Azzam Pasha appeared in Tucumán's La Gaceta and El Eco de Oriente. He outlined similarities between the Latin American and Arab blocs in the context of their representation in the United Nations, stating that: 'The countries of Latin America have affinities and interests in common in terms of their collective defence, geographic proximity, linguistic unity and cultural ties' with

30 'Amistad y solidaridad argentino-egipcia', ibid., ro Aug. 1953, p. 36.

31 'Actividades de la colectividad árabe: Santiago del Estero', Mundo Árabe (Córdoba), i 9 Dec. 1953, p. 2. 


\section{Lily Pearl Balloffet}

the Arab bloc countries. He compared the two areas' history of regional solidarity by drawing a parallel between the 'Act of Chapultepec' and the 'Alexandria Protocols'. The former referred to the 1945 Panamerican Treaty signed at the Conference of Chapultepec in Mexico City that acted as a precursor to the 1947 Rio Pact, a security agreement invoked in the name of hemispheric defence as the Americas entered the Cold War era. In a similar vein, the 'Alexandria Protocols', signed by the five founding Arab League states in 1944, promoted the coordination of foreign policy and national defence agendas by the pact's signatories. Commenting to the Argentine press, Azzam conspicuously omitted the detail that in 1945 Argentina refused to sign the Act of Chapultepec. Instead, he chose a revised version of events to emphasise similarity between Latin American and Arab regional history for his Argentine audience. ${ }^{32}$ Azzam's statement is evidence of Egyptian officials' desire to portray affinity between Latin American and Arab identities and histories.

General Naguib also reached out to the Argentine public via the platform of Arab-Argentine press organs. In a May 1953 meeting with América y Oriente's Cairo-based correspondent, Naguib gave an interview which he concluded with remarks about the future of Arab-Latin American relations:

Egypt welcomes all friendly nations which extend their hand and aid [Egypt] in her struggle for liberty. We want to maintain friendly and cordial relations with these nations. We will exert our most concerted efforts to realise cultural and economic treaties. This is the way in which we view [Latin America]. ${ }^{33}$

By the end of that year, steps toward Naguib's promise of 'cultural treaties' with Latin American nations materialised. A December 1953 news brief in Córdoba's Mundo Arabe reported that

The Iberoamerican Cultural Centre has been inaugurated [in Cairo]. Present at the ceremony were Argentine, Brazilian, Chilean, Uruguayan, Portuguese, French and Spanish diplomatic representatives. It was announced that the Spanish language will be taught in the Centre's Foreign Language School. ${ }^{34}$

Here, we see the rhetoric of solidarity and affinity backed by concrete initiatives from the revolutionary government, such as the establishment of the Cultural Centre.

32 'La América Latina y el mundo árabe-asiático', El Eco de Oriente (Tucumán), i I July i 952, p. I.

33 'Declaraciones del General Naguib para América y Oriente', América y Oriente (Buenos Aires), io May 1953, p. I 5.

34 'El Cairo, 15', Mundo Arabe (Córdoba), is Dec. 1953, p. 2. 
Channels of communication also extended beyond the diaspora to the realm of the state, yet this dimension of the South-South dialogue tends to be ignored by the scholarly literature prior to Nasser's rise. Naguib also contacted Perón and his cabinet directly on multiple occasions between 1952 and 1954. In commemoration of the first anniversary of the Revolution, he wrote to the Argentine Congress to express his 'sincerest thanks, and affirmations of the greatness of the Argentine nation'. ${ }^{35}$ His thanks were in response to a lavish celebration of the Egyptian Revolution that took place at the Teatro Nacional Cervantes in Buenos Aires. The event filled the ornate theatre, which was 'decked out in a profusion of flags and Egyptian national symbols'. In attendance were important functionaries such as Minister of Foreign Relations Jerónimo Remorino (successor to Paz), Minister of the Interior Ángel Borlenghi, Eduardo Vuletich - Secretary-General of the main trade union federation Confederación General de Trabajadores - and Egyptian Ambassador Mahmoud Moharram Hammad. ${ }^{36}$ A few months prior to the celebration, when Hammad returned to his Buenos Aires post after a Cairo visit, Naguib sent the following message to be relayed directly to Perón: 'Naguib is a fervent admirer of Perón and his masterpiece - that which he is elaborating for the greatness of his patria and for the triumph of the Third Position.' He concluded his message with a reference to the anti-imperial struggle that would define the revolutionary government in the years after 1952: the battle for control over the Suez Canal. He decried British incursions into Egyptian territory: 'The Egyptian people are fighting to dislodge the English from the strip of land that extends along the banks of the Suez, and which is totally Egyptian in fact and by right.' 37 Over the course of the I950s, anti-imperial struggle was one of the most prevalent topics in both Argentine and Arab discourses on the common trajectories of the Egyptian and Argentine peoples.

\section{Perón in Exile: Arab-Argentines as Interlocutors}

Recently, historian Diego Olstein has called for scholars to '[bring] history out of the national box' by considering Perón's 1946-55 administration in global perspective. ${ }^{38}$ One strategy for globalising our understanding of Peronism is to plot lines of comparison between national leaders or international policy doctrines. To this end, scholars have already noted overlaps in rhetoric and corporatist policy between Peronism and Nasserism. Robert Bianchi described Nasserism as 'a fascinating and often intentional Egyptian counterpart to

35 'El General Naguib contestó un mensaje', El Eco de Oriente (Tucumán), Io Aug. I953, p. 2.

36 'Rindióse homenaje a Egipto en el primer aniversario de su liberación', ibid.

37 'Regresó el ministro egipcio', ibid., 9 June 1953, p. I.

${ }^{38}$ Diego Olstein, Thinking History Globally (New York: Palgrave Macmillan, 201 5), p. 9. 
Peronism'. ${ }^{9}$ Accordingly, the memoirs of Free Officer Abdal Latif alBoghdadi confirm that, during the transition from the leadership of the Revolutionary Command Council (RCC) headed by Naguib to that of Nasser, elite circles of the armed forces regularly debated aspects of Peronism as they discussed the maintenance of military rule vs. the return to multiparty politics. ${ }^{\circ}$ In foreign policy, Diego Olstein and Hishaam Aidi have both noted the similarities between Perón's and Nasser's philosophies of non-alignment in a Cold War world (Perón's 'Third Position' and Nasser's 'Positive Neutralism'). ${ }^{41}$ In retrospect, Nasserism certainly shared many defining features with Latin American populism, as articulated by Elie Podeh and Onn Winckler. These included 'the central role of the charismatic leader and the special bond with the masses; the authoritarian nature of the regime, with its various techniques of mobilization among broad stratums; and the regime's eclectic use of ideology'. ${ }^{42}$ Collectively, extant scholarship renders a compelling picture of similarities between Peronist policy and early Nasserist Egypt.

However, this focus on parity of style often elides the mechanics of influence between the two leaderships, and risks situating the two as spontaneously parallel phenomena. The activities and memories of state actors such as Ambassador Speroni, alongside Arab interlocutors such as the journalist Mattar, show a concerted intention to incorporate Argentine modes and ideas into the Egyptian revolutionary project beginning with Naguib's tenure, and continuing through the rise of the NAM. Furthermore, relying on the periodisation of Perón's time in office, or the Egyptian Revolution only from Nasser's assumption of power in 1954, risks limiting our understanding of the entangled nature of Argentine-Egyptian history outside the confines of these temporal guideposts. At the beginning of the period, it ignores the important exchanges during Naguib's tenure, and from its end it precludes networks of solidarity that continued to function well after Perón's i 955 exile.

With respect to the pre-Nasser era of the Revolution, the eagerness of both Argentines and Egyptians to recognise their countries as 'sister nations' (in Perón's words) is clear. Although Perón was driven into exile when his first government ended with a coup in 1955 - some eight months after the RCC appointed Nasser president - he continued to strive for a closer

39 Robert Bianchi, Unruly Corporatism: Associational Life in Twentieth-Century Egypt (New York: Oxford University Press, 1989), p. 28.

${ }^{40}$ Kirk J. Beattie, Egypt during the Nasser Years: Ideology, Politics, and Civil Society (Oxford: Westview Press, 1994), p. I22.

${ }^{41}$ Olstein, Thinking History Globally, p. I 3; Aidi, Redeploying the State, p. 6I.

${ }^{42}$ Elie Podeh and Onn Winckler, 'Introduction: Nasserism as a Form of Populism', in Podeh and Winckler (eds.), Rethinking Nasserism: Revolution and Historical Memory in Modern Egypt (Gainesville, FL: University Press of Florida, 2004), pp. I-42, here p. 28. 
relationship with important members of the Egyptian government. Even while he was in exile, the Arab-Argentine community managed to facilitate Perón's contact with Egyptian political actors. In addition, the opportunities that the Arab-Argentine community had created for him to interact with Egyptian diplomats during his time in office created lasting contacts for him while he was in exile in the Dominican Republic and then Madrid. In sum, the diaspora community had already laid the foundations for a lasting relationship between Argentine and Egyptian politicians that would extend beyond the limits of Perón's presidential rule.

A flurry of correspondence that Perón dispatched to Egypt in 1959 provides insight into his continued interest in Argentine-Egyptian relations well into his exile. In one letter, penned from the Dominican Republic, Perón wrote to Nasser. He conveyed admiration for Nasser's 'patriotic enterprise', adding that he had carefully followed the Revolution since its inception. ${ }^{43}$ Later, Perón wrote from Madrid, where he remained until his return to Argentina in 1973. Syrian-Argentine businessman Jorge Antonio - one of Perón's closest financial advisors - accompanied him for much of his exile in Madrid, and recalled that

[Perón] had great sympathy and good dealings with the Arab nations while he was in exile ... He was a personal friend of Nasser, and they wrote back and forth often. I was his interpreter, and went to Egypt various times in order to relay things from Perón to Nasser, and from Nasser back to Perón. ${ }^{44}$

In other letters to Egypt in 1959, Perón repeatedly noted his use of ArabArgentine businessmen as couriers for mail to Egypt. Before he went to Madrid, Elias Abud, a prominent Syrian-Argentine from Buenos Aires, travelled to Ciudad Trujillo to ferry his letters to Cairo.

Perón also contacted important functionaries in the Egyptian government such as Zeki Djebi and Hassan Ismail Fahmi - respectively Minister of Foreign Relations and Director of the Latin America Foreign Ministry Division. ${ }^{45}$ In his letters to both men he assured them that he had kept abreast of the trajectories of their diplomatic careers since meeting them personally in Argentina. As with Nasser, we witness the facilitating role of Arab-Argentines in creating avenues for exchange between their national leadership and Arab politicians. Before being ousted, Perón had had opportunities to encounter these two

43 Juan Domingo Perón, letter to Gamal Abdel Nasser, 28 Jan. 1959. Juan Domingo Perón Papers, I93 I-2002, Hoover Institute Archive, Stanford University, Stanford, CA (hereafter JDPHI).

44 Abdeluahid Akmir, Los árabes en Argentina (Rosario: Editorial de la Universidad Nacional de Rosario, 201 I), p. 256.

45 Juan Domingo Perón, letter to Dr Zeki Djebi, Jan. 1959, JDPHI; Juan Domingo Perón, letter to Hassan Ismail Fahmi, Jan. 1959, ibid. 
diplomats at functions hosted by members of the Arab-Argentine community. Fahmi, who had served as military attaché to the Egyptian Legation in Buenos Aires in the 1950s, and Djebi, the first official Syrian minister in Argentina, were regular attendees at Arab heritage association dinners and celebrations. ${ }^{46}$ Djebi had close ties with members of the Arab-Argentine community who, for many years, had lobbied for Syria and Argentina to open diplomatic relations, and celebrated Djebi's i 945 assignment to his Buenos Aires post. It was Djebi who conferred the Syrian government's highest medal of honour, the 'Order of the Umayyads', upon Eva Perón in April 1952 - only a few months before her death - amid great celebration from the Arab-Argentine press. ${ }^{47}$ By 1959, the Syrian diplomat found himself working in Cairo, as a result of Egypt and Syria's official declaration in February 1958 that they would federate as the United Arab Republic (said federation lasted from I958 to 1961).

In his letter to Djebi, Perón leaned heavily on the language of non-alignment, promoting the vision of a united Arab world, 'happy owner of her own destiny'. He remarked on the 'triumph of Nasser, surrounded as he is by the great powers, without allowing himself to become trapped by the powerful interests of his aligned enemies' ${ }^{48}$ Once again, Perón employed the language of the NAM, which in 1959 was still in its infancy. (It was not until 1961 that the NAM was formally established at the Belgrade summit meeting.) To Fahmi - tactfully reassuring an Egyptian audience that Peronism still wielded power in Argentina - he wrote:

The people have begun to rebel ... As of 16 September 1955 , there were 5,000,000 Peronist votes we could count on. Now there are more than $7,000,000$. Soon everyone will recognise the great benefits for the people and the country that come from Peronism in power. Sooner or later, recuperation of the government is inevitable. In the meanwhile, it is with great satisfaction that I share the triumph of Egypt in this tremendous struggle which signifies total popular and national liberation. ${ }^{49}$

While he was writing from exile in 1959, Argentina was experiencing economic recession, military-imposed austerity measures and civil unrest. Perhaps spurred by these uncertain times on the home front, Perón reached out to Egyptians, whom he perceived as strategic global allies in the future of the Peronist movement. The content of Perón's correspondence demonstrates that he not only admired the Egyptian revolutionary project and its key leaders, but, furthermore, was concerned that the Egyptian government should recognise the sway that he held in Argentina despite his exile.

\footnotetext{
46 'Se aleja de nuestro país el ministro de Siria', El Eco de Oriente (Tucumán), i 2 Jan. I 953 , p. I.

47 'Siria condecoró a la Señora Eva Perón', Assalam (Buenos Aires), i 8 April i952, p. I.

${ }^{48}$ Perón, letter to Zeki Djebi.

49 Perón, letter to Hassan Ismail Fahmi.
} 
By 1960 , there is evidence that Perón explicitly advised followers in Argentina to view the cooperation of Arab bloc countries as an example to emulate. To militant labour organiser and Resistencia peronista member Avelino Fernández he wrote:

The world today ... forms a single unit, as divided as it may seem. What is happening in Algeria resonates on other continents, and what Russia and the United States do ... has repercussions across the rest of the globe. There is a deep woven interdependence, first because of economic interests, and now because of ideological interests. Restrictive nationalities that raised impassable borders between countries have ceased to exist, and the realisation that everyone's destiny is at stake has driven the formation of national blocs. ${ }^{50}$

He cited Africa and the Middle East as primary examples of regions that formed regional alliances, such as the Arab League. Analysis of Perón's exile correspondence both to Egypt and to constituents in Argentina adds new layers on two fronts to the study of Argentine-Egyptian relations in the twentieth century: first, it demonstrates the continued role of diasporic Arabs in mediating the relationship between Peronism and Nasserism even after the 'Revolución Libertadora' coup that ended Peron's presidency in 1955; second, it represents a step toward excavating a broader regional history of informal relationship to the NAM during the early Cold War. Perón's fascination with the Egyptian project closely resembled that of other Latin American leaders at the turn from the i950s to the 1960s. Examples of this regional trend include Che Guevara, with his three-month tour of I 4 Bandung Pact countries (including Egypt) in 1959, what one scholar deemed Mexico's early 1960s 'flirtation' with the NAM,5' and Jânio Quadros (president of Brazil for seven months in 196I) who, John Karam notes, was 'particularly fond of' Nasser and 'declared what he called Brazil's ... Independent Foreign Policy' before being overthrown by the military. ${ }^{52}$ Much as Karam argues in the Brazilian case, in Argentina we see a Latin American leader who 'learned the keywords of nonalignment', and 'eventually used [that language] to frame ... increasingly closer ties with the Middle East'. ${ }^{53}$ This brings us to

so Juan Domingo Perón, letter to Avelino Fernández, i 8 June 1960, JDPHI. The 'Peronist Resistance' was a grassroots movement of Peronist sympathisers which carried out clandestine acts of sabotage against the military government during the years immediately following the 1955 coup.

${ }^{51}$ Vanni Pettinà, 'Global Horizons: Mexico, the Third World, and the Non-Aligned Movement at the Time of the 1961 Belgrade Conference', The International History Review, 38: 4 (2016), pp. 741-64.

52 John Tofik Karam, 'Beside Bandung: Brazil's Relations toward the Arab World', LASA Forum, 47: I (2016), p. 26.

${ }^{53}$ Ibid., p. 30. 


\section{Lily Pearl Balloffet}

our final temporal fulcrum for constructing an entangled Argentine-Egyptian history at mid-century: the 1956 Suez Canal conflict.

\section{Suez}

As tensions over the Suez Canal zone escalated throughout the mid-r950s, and came to define the early Nasser years, the canal became a flashpoint for comparison and identification with anti-imperialist sentiments in Argentina both before and after Perón's exile. This section gives a brief review of the Suez Canal conflict followed by analysis of why this moment was an important flashpoint for many Argentines. The Suez Canal symbolised unique forms of transnational solidarity and historical parallels for diverse sectors of Argentine society, as well as the transnational public sphere of the Arab Diaspora. Argentines took an interest in these events in Egypt for various reasons: cultural or ethnic heritage ties, a sense of relevancy to the labour movement, or as fellow citizens of the global 'periphery'. This nuanced perspective challenges previous views on the influence of Nasser-era politics in Latin America that downplay the possibility of variegated forms of empathy or solidarity on the part of Latin American citizens with the specifics of the Egyptian cause. 54

By 1956, the Suez Canal had been in operation for nearly a century under de facto British control via stakeholding in the Suez Canal Company, and the Constantinople Convention declaration that had placed the Canal Zone under British protection since i 888. When Nasser nationalised the Suez Canal Company in July 1956, his actions were part of a series of Cold War power plays involving figures such as US Secretary of State John Foster Dulles and British Prime Minister Anthony Eden. As the RCC sought to consolidate the Revolution post-1952, they pushed forward an agenda of largescale agrarian reform, industrialisation and sovereignty from European occupation of the Canal Zone. The leaders of both the RCC and the USSR and United States knew that the necessary infrastructure and energy needs for this agenda were linked to the completion of the Aswan Dam - a major hydroelectric project. Between 1955 and I 956 Nasser stubbornly adhered to his political stance of 'Positive Neutralism', attempting to obtain funding from both the United States and the USSR to advance the construction at Aswan - a position that irked US strongmen such as Dulles. In early July 1956, Dulles abruptly withdrew the US\$56 million-dollar funding package previously offered for the dam project. He banked on the United States' ability to call a Soviet bluff regarding more than a billion dollars in arms deals and construction loans, but, as a gamble to humiliate Nasser, it was a resounding failure. Soon thereafter (26 July) came Nasser's announcement of his decision to

${ }^{54}$ Kaufman, Shapira and Barromi, Israel-Latin American Relations, p. 49. 
nationalise the Suez Canal Company to subsidise Aswan. Throughout the Global South, people who had long struggled against colonial and imperial yokes celebrated Nasser as a hero, and avidly followed the conflict.

Support for Egypt's position in the Suez Canal conflict spread quickly. In the Levant, hundreds of thousands of people rallied in popular support of Nasser. ${ }^{55}$ Following the canal's nationalisation, Israeli, British and French forces invaded Egypt in hopes of regaining control. The Egyptian military managed to keep the waterway blocked to all shipping, and Israel, France and Britain withdrew from Sinai and the Northern Canal Zone under heavy pressure from the United States, the Soviet Union and the United Nations. In the eyes of many international onlookers, the withdrawal was a watershed moment for General Nasser. He became a symbol of global antiimperialism. Throughout the Global South, many attributed his successful maintenance of the Canal Zone to his strategy of non-alignment - a move that had ultimately pitted the United States against her European allies. For many Arabs in the Middle East, Nasser's triumph invigorated their hope for the liberation of Palestine through a combination of non-alignment - a strategy that appeared to have the power to counter imperialism - and armed struggle. This episode's magnitude in the global struggle against imperialism, as well as its implications in the Arab-Israeli conflict, reverberated in Latin America and throughout the Mahjar's public sphere.

From Panama to the Southern Cone there were marches and demonstrations in support of Egypt after the Suez affair. In Buenos Aires, public manifestations began on the night of the tripartite invasion, and marchers chanted 'Argentina with Egypt!'s6 In the following months, Arab-Argentine heritage organisations, intellectuals and university students echoed this sentiment. Indeed, by 1956, the 1952 Revolution's agenda and trajectory were more central to civilian discussions of imperialism, non-alignment and international diplomacy than ever. 'I believe that the struggle for the Suez Canal had a great deal of positive influence in the colectividad', recalled Syrian-Argentine writer, intellectual and political activist Fernando Nadra. 'When the British and the Israelis attacked, this raised up the figure of Nasser before all of us, and there was a great movement in support of the Egyptian cause - the cause of the Arabs.' 57 For some Arab-Latin Americans, their views of the Egyptian victory at Suez were influenced by deeply personal connections to a Palestinian homeland. At least one diasporic Arab went so far as to cable Nasser directly. Her message read: 'President Nasser. Cairo, Egypt. Invoking

s5 James Jankowski, Nasser's Egypt, Arab Nationalism, and the United Arab Republic (Boulder, $\mathrm{CO}$ and London: Lynne Rienner Publishers, 2002), p. 83.

${ }^{56}$ Vélez, Latin American Revolutionaries, p. I 6.

57 Akmir, Los árabes en Argentina, p. 235. Nadra was a long-serving leader of the Argentine Communist Party. 


\section{Lily Pearl Balloffet}

your brave spirit, I beg the Egyptian people not to give up an inch of your stake. This attitude will save Palestine, my homeland. Nazarena Lama, Santiago [de Chile].' 58

At the associational level, Arab-Argentine organisations mobilised to express solidarity with Egypt or a pan-Arab cause. In 1956 two long-running organisations - the Club Honor y Patria (established 1932), and the Patronato SirioLibanés (1928) - merged to form the 'Honour and Fatherland Club, Union of Arab-American Peoples'. The long-dormant 'Federation of Arab Bodies in the Argentine Republic' issued a communiqué on Is August 1956 in response to the invasion, and called for a general strike by members of the collectivity in solidarity with Egypt. Charitable organisations mobilised, with campaigns such as that of the Islamic Centre Women's Commission in Buenos Aires, who raised funds to send to Egyptian victims of the fighting in Suez.59 Other groups held public meetings to discuss and honour Nasser's decision to nationalise the canal, including the Homs Club of Buenos Aires, the Argentine-Arab-Latin-American Congress for Solidarity, Peace and Freedom, the Arab Argentine Home Association of Berisso and the Lebanese House of Buenos Aires, and organised press conferences hosted by the Syrian and Egyptian legations and the Rotary Club of Cairo. ${ }^{60}$ From charity campaigns to heritage associations that adopted new names, a focus on Nasser's anti-imperialist non-alignment, combined with an evocation of solidarity between Argentina and Egypt, were the salient themes. In 1956, it was these that defined discourses of anti-imperialism in the writings of Arab-Argentine intellectuals, university conferences and the labour movement. Solidarity with Egypt was a common language that appeared in the I950s, bridging different sectors of Argentine society. Though the Egyptian context was new, it was a register that meshed seamlessly into the pre-existing tradition of invoking the right to sovereignty as a key component of national dignity that had appeared in Argentine political discourse since the nineteenth century. ${ }^{61}$

Comparisons between British incursions in the Suez Canal and the Islas Malvinas (Falkland Islands) were one way that people expressed the affinity they perceived between Argentine and Egyptian realities. These comparisons appeared before the Suez conflict, in Perón's assessments of the 1952 Revolution, and they proliferated after Nasser's declaration of nationalisation. As early as 1953, Perón responded to a message from General Naguib

58 'Petición a Nasser', Mundo Árabe (Santiago de Chile), 17 Aug. 1956, p. I I.

59 Hamurabi Noufouri, Sirios, Libaneses, y Argentinos: Fragmentos para una historia de la diversidad cultural argentina (Buenos Aires: Fundación Los Cedros, 2005), p. 287.

${ }^{60}$ DAIA, Anti-Jewish Activities, pp. 17-2 I.

${ }^{61}$ For discussion of sovereignty in Argentine political discourse: Michael Goebel, Argentina's Partisan Past: Nationalism and the Politics of History (Liverpool: Liverpool University Press, 201 I), pp. 193-7. 
proclaiming that it was 'the struggle for liberty for the people which links the sentiments and aspirations of [Argentina and Egypt]':

Great Britain occupies the Canal Zone by force in the same manner that she occupies the Malvinas ... The situation is the same. It is like a thief who one day steals a dog and the next day comes back and demands that the owner provide him with the leash as well. A country can't be half independent - either it is or it isn't. ${ }^{62}$

This comparison also appeared centrally in the book by Arab-Argentine intellectual and Arab League liaison officer Ibrahim Hallar published during the Suez conflict and entitled The Dreams of Colonel Nasser are White and Sky Blue, Like the Emblem of the Argentine Nation. Seizing on the SuezMalvinas theme, Hallar wrote:

If we imitate the example of the Egyptian people in expelling the English from our Malvinas, we will not be committing any crime against that country; on the contrary, our spirit would become fortified, our Argentinista conscience would affirm itself more and more each day. ${ }^{63}$

For Hallar, 'imitating' Egyptian actions was something that could deepen and affirm Argentine anti-imperialist consciousness.

Voices from the Argentine Left and labour movement shared this language, despite their political differences from the traditionally more middle-class and centrist Arab-Argentine political and journalistic circles. The Argentine Communist Party (PC) was openly pro-Arab during the tripartite invasion (largely owing to the USSR's support of the canal's nationalisation), and pro-Nasser articles appeared regularly in their principal press organs, such as Nueva Era. ${ }^{64}$ Press coverage often framed Argentina and Egypt as bound together in a unified working-class struggle against imperial interests. Particularly vocal was Fernando Nadra, who extended his comparison of the Argentina-Egypt binary to encompass a regional Latin American history of landscapes physically scarred by imperialism. In the aftermath of the Suez struggle, he wrote:

The managers of this foul enterprise (as wealthy in dollars and pounds as they are in the blood of the people), which is based upon the 'Western rights' over the Suez Canal, are the same people who are the beneficiaries of the Panama Canal, of the

62 'Declaraciones del General Perón'.

${ }^{63}$ Ibrahim Hallar, Los sueños del Coronel Nasser son celestes y blancos como el emblema de la nación argentina (Buenos Aires: Ibrahim Hallar, 1956), p. 9, in Biblioteca Nacional, Buenos Aires.

${ }^{64}$ Mercedes Saborido, "De "defensores de una causa santa" a "lacayos del imperialismo". El Partido Comunista de la Argentina y el conflicto de Suez (1956)', Cuadernos de Historia Contemporánea, 35 (2013), pp. 193-218. 


\section{Lily Pearl Balloffet}

fruit trees and the cane fields of the Caribbean, of the Bolivian situation, of Chilean copper, of Brazilian coffee, of Argentine meat and wheat ... and of so many other riches produced by the sweat and misery of Latin Americans ... The cause of the Egyptian people is our cause. We could not seriously be patriots, we would not be doing everything in our power to assure our own national independence, if we did not feel for the cause of independence of other peoples. ${ }^{65}$

For Nadra, the basic unit of human suffering upon which the two canals were constructed was an inescapable factor that bound these two world regions together via a common history of exploitation.

Meanwhile, in the Labour Party's official newspaper, El Laborista, more than 80 articles on Egypt and the canal appeared in September and October of 1956 alone. Founded by Peronist union leaders in 1945, but forcibly dissolved in 1946 by Perón, Argentina's Labour Party reappeared after his exile in 1955 under the leadership of Cipriano Reyes. Reyes, a union leader in the meat-packing warehouses, was on the frontlines of organised labour that brought Perón to power, but was subsequently repressed by the regime once it began to drastically consolidate political parties under the all-subsuming Justicialist Party. When Reyes reappeared as a central figure in the neoPeronist Labour Party in I955, he represented a movement that was deeply critical of the current military dictatorship, was pro-labour, yet opposed to Perón serving as the movement's figurehead. ${ }^{66}$ Only weeks after Nasser declared the nationalisation of the Suez Canal Company, Reyes began to make appearances at pro-Egypt/Nasser-themed events. On I9 August I956 Reyes acted as a guest speaker at the Association for Arab Culture in the Argentine Republic, and a few days before that he was the guest of honour at an homage to Nasser hosted by the Homs Club. Similar associations emerged among politicised groups of university students which, though largely unaffiliated with the Labour Party, shared the language of an Argentina-Egypt connection.

In November 1956, the Buenos Aires branch of the University Reform Movement (MUR) published extensive analysis of current events in Egypt and the Middle East. They emphasised the widespread popular solidarity toward Egypt, citing the profusion of lively discussions, marches, conferences and publications that emanated from university faculty and students. At the University of Buenos Aires, demonstrations in support of Egypt took place at the medical and law schools, and universities in the federal capital broadcast special radio transmissions to express students' 'instinctual solidarity with the

${ }^{65}$ Fernando Nadra, Egipto, Suez, y el mundo árabe (Buenos Aires: Editorial Fundamentos, I957), p. I.

${ }^{66}$ Robert A. Potash, 'Argentine Political Parties: 1957-1958', Journal of Inter-American Studies, I: 4 (1959), p. 521. 
Egyptian people'. ${ }^{67}$ To articulate their solidarity with 'not just Egypt ... but the Arab world', the MUR turned to the language of Argentine economist Raúl Prebisch, whose structuralist approach to global economics emphasised a core-periphery dichotomy.

Being as we are a 'peripheral country', we have a responsibility to support ... without reservation the attitude assumed by the Egyptian leader, given that [his action] embodies an anti-imperialist struggle of which all Latin American nations in general, and Argentina in particular, are currently a part. ${ }^{68}$

Overall, the enthusiasm for Nasser's Suez agenda expressed by university groups, taken alongside that of Argentina's Labour Party and PC, indicates that Argentines who identified with the Nasserist agenda were not simply Peronists interested in elevating a perceived Arab version of their own former leader. Nor were they strictly Argentines of a broader Left - veneration for Nasser came from within the ranks of the Argentine military even after the 1955 coup. Argentine journalist Rogelio García Lupo observed that, by 1959, 'Nasserism exercised an irresistible attraction on young [army] officials.' ${ }^{69} \mathrm{~A}$ decade after Argentina commenced its formal diplomatic relationship with Egypt in 1947, the Suez moment generated an amalgam of pro-Egypt solidarity extending far beyond Argentina's Mahjar. This support - often expressed as a belief in an Argentine-Egyptian connection - appeared across sectors of Argentine society with distinct social and political agendas, yet who shared a language of solidarity with Egypt and to some extent the NAM. Traditional diplomatic history would at this moment outline a vision of Argentina turning away from the NAM and the Arab world. After all, in the wake of Perón's exile, the foreign policy of the leaders of the Revolución Libertadora was much more openly aligned with US interests. But approaching this era instead as an intermingled panorama of civilian groups and their relationship to the idea of Egyptian sovereignty provides us with a different vision of this historical moment. In the end, it is not necessary to view the potential divergences between Argentine political rhetoric vs. policy vs. expressions of popular sentiment as contradictory in themselves. Indeed, it is within these modes of relating to Egypt and its revolutionary process that we witness the overlapping, and sometimes oppositional, programmes and postures that circulated in Argentina, and the wider Global South, during the Cold War.

${ }^{67}$ Cuadernos de Movimiento Universitario Reformista, La nacionalización del canal de Suez: Introducción al estudio del proceso económico-social del Medio Oriente (Buenos Aires: Prensas Universitarias Argentinas, 1956), p. 7.

${ }_{68}^{68}$ Ibid., p. Io.

${ }^{69}$ Rogelio García Lupo, La revolución Nasserista (Buenos Aires: Proceso, I 962), p. I I. 


\section{Conclusions}

Through analysing the three dimensions of the developing ArgentineEgyptian relationship at mid-century, I have argued that Argentine people and politics were influential in the Egyptian revolutionary project. From diasporic interlocutors to activists and diplomats, Argentines offered a discursive model, intellectual base and demonstration of Global South solidarity with Egypt. These solidarities ran far deeper than previously acknowledged by literature on Argentine-Egyptian relations, and preceded the rise of the NAM. There were not merely spontaneous discursive similarities between national leaderships. This article traces lines of transmission and influence in the realm of political theory and praxis made possible by pre-existing traditions of anti-imperial activism and through diasporic networks linking South America to the Arabic-speaking Eastern Mediterranean. Thus, overlaying a history of Argentine international relations with narratives of human migration allows us to achieve a more accurate rendering of the state of ArabLatin American relations during this period. It also reveals the diverse ways in which historical events in the Arab world resonated with, and mattered to, Argentines from diverse ethnic, social and political sectors.

Methodologically, constructing this bridged history draws us closer to a new historical model of international relations that goes beyond diplomacy, and interfaces with other realms of social and cultural life. Narratives of travel, diaspora and anti-imperial activisms come to bear on this 'New International History' of Latin America and the Middle East. ${ }^{\circ}$ This relational model reveals the meaningful ways in which these two regions have been entangled beyond state-sanctioned diplomacy through (among other things) avenues of migration and anti-imperialism.

Ultimately, we cannot fully measure Latin America's movement toward or away from global phenomena solely by observing the tides of statecraft. We must also consider how the state's diverse public identified itself in relation to these global trends or events, such as the Egyptian Revolution, Suez, or the NAM. As John Karam notes, Latin American states learned the language of the NAM and used it as they inched closer to Arab nations over the years. ${ }^{7 r}$ This article makes clear that non-state actors and groups (whether of the Arab diaspora, the Left, or deposed political parties) also learned and deployed this language for their own ends. Methodologically, 'connected history' of two nations opens the field of their respective national histories to new vantage points, suggests Sanjay Subrayhaman. ${ }^{72}$ We thus reveal 'multifaceted

70 Olstein, Thinking History Globally, p. I 5.

${ }^{71}$ Karam, 'Beside Bandung', p. 26.

${ }^{72}$ Cited in Caroline Douki and Philippe Minard, 'Histoire globale, histoires connectées: Un changement d'échelle historiographique?', Revue d'Histoire Moderne et Contemporaine, 5: 54 (2007), pp. 7-2r. Quotations are from the English version, 'Global History, 
interactions, beyond ... political partitions (national or imperial) and on various scales'. By 'moving laterally [we] identify connections that had been hitherto hidden or unseen' ${ }^{73}$ In this light, the study presented here of Argentine-Egyptian history serves as an invitation to other scholars of Latin America, Africa and the Middle East to venture a 'lateral step', and illuminate new dimensions of the multifaceted networks that have historically bound these regions together. For scholars of migration and diaspora, this article proposes a model for integrating ethnic and diaspora histories into regional histories of diplomacy, and dialogues about alignment that took place in the early Cold War era.

\section{Spanish and Portuguese abstracts}

Spanish abstract. Este artículo presenta una historia de interrelaciones entre Argentina y Egipto en los años alrededor de la Revolución Egipcia de 1952. El artículo combina historias diplomáticas, migratorias y de activismo anti-imperial para delinear los vínculos intelectuales e institucionales entre estas naciones desde fines de los años 40 a los 50 - desde el ascenso del peronismo hasta el manejo de Nasser de la crisis del Canal de Suez en 1956. Diversos sectores sociales y políticos argentinos vieron paralelos entre las luchas anti-imperiales del mundo árabe y las de Latinoamérica. Aunque con agendas diferentes y alguna vez enfrentadas, estos grupos aprendieron y utilizaron los lenguajes del no alineamiento y de la solidaridad Sur-Sur dentro de la creciente Guerra Fría.

Spanish keywords: Argentina, Egipto, sur global, diáspora árabe, Guerra Fría, Movimiento no alineado

Portugese abstract. Este artigo apresenta uma história entrelaçada da Argentina e do Egito nos anos acerca da revolução Egípcia de 1952. Combina histórias diplomáticas, da migração e do ativismo anti-imperialista para delinear as conexões intelectuais e institucionais entre as duas nações desde o final dos anos quarenta até os anos cinquenta - da ascensão do Peronismo até a gestão de Nasser sobre a crise do canal de Suez de 1956. Diversos setores políticos e sociais da Argentina enxergaram paralelos na luta anti-imperialista do mundo Árabe e da América Latina. Apesar de objetivos diferentes e muitas vezes concorrentes, esses grupos aprenderam e acionaram a linguagem de não-alinhamento e de solidariedade sul-sul na guerra fria que se escalava.

Portuguese keywords: Argentina, Egito, sul global, diáspora árabe, Guerra Fria, Movimento de não-alinhamento

Connected Histories: A Shift of Historiographical Scale?', available at https://www.cairnint.info/article-E_RHMC_545_0007--global-history-connected-histories.htm (last access 21 Oct. 2017).

73 Ibid. 